Svanström (toim.), Metod. Guide för historiska studier s. 97-133. Lund: Studentlitteratur.

Richter, Melvin 1995: The history of political and social concepts. New York: Oxford University Press.
Tognini-Bonelli, Elena 2001: Corpuslinguistics at work. Amsterdam: John Benjamins.

Tully, James (toim.) 1988: Meaning and context. Quentin Skinner and his critics. Princeton: Princeton University Press.

\title{
Lukutaito emansipaation välineenä ja yhteisön voimavarana
}

Tuija Laine: Aapisen ja katekismuksen tavaamisesta itsenäiseen lukemiseen. Rahvaan lukukulttuurin kehitys varhaismodernina aikana. Helsinki: Suomalaisen Kirjallisuuden Seura 2017. 210 s.

ISBN 978-952-222-862-8.

Tuija Laine piirtää tiiviissä, parinsadan sivun teoksessaan suomalaisten lukutaidon isoja kaaria noin 300 vuoden ajalta, 1500-luvun lopulta 1800-luvulle. Hän tarkastelee rahvaan lukukulttuuria ennen muuta Suomessa mutta sijoittaa maan tarvittaessa Ruotsin yhteyteen - niin kuin noiden vuosisatojen tarkastelussa kuuluukin - ja edelleen osaksi Pohjoismaita ja Eurooppaa.

Kirjassa kuvataan lukutaidon kehitys ulkoluvusta kohti modernia itsenäistä lukemista. Kirja perustuu Laineen työhön kirjahistorian professorina ja yhteistyöhön muiden kirjahistorian tutkijoiden kanssa ennen muuta teologian, kirkkohistorian ja historian viitekehyksessä. Laine edustaa tieteenalan sosiaalihistoriallista suuntausta, jossa lukutaitoa ja kirjoja tarkastellaan yhteisön ja yhteiskunnan näkökulmasta: kenellä oli mahdollisuus lukea, mitä kirjoja oli saatavilla, miten lukutaito vaikutti lukijoiden elämään ja niin edelleen.

Kirjan alaotsikko kohdistaa huomion nimenomaan rahvaan lukukulttuuriin.
"Rahvas" tarkoittaa Laineen kielenkäytössä kansanihmisiä eli talonpoikia ja säätyjen ulkopuolisia. Yläpuolella olevat hallitsijat ja oppineet kannustivat, ohjasivat ja edistivät rahvaan lukutaitoa tai kurittivat lukutaidottomuudesta. Rahvaan lukutaidon tarkasteleminen on vastakkainen tai täydentävä - suunta sille kirjahistorian painotukselle, jossa kirjojen ja lukutaidon historiaa kirjoitetaan tarkastelemalla kalliita loistopainoksia, hienoja kuvituksia ja käsityötaidon ihmeitä ja jossa lukutaitoa edustavat papisto ja munkit.

Kirjan johdantoluku problematisoi rahvaan näkökulmaa monelta kannalta. Laine lähtee liikkeelle historiantutkija Robert Darntonin ajatuksesta, jonka mukaan kirjahistorian tutkimuksessa tulisi ottaa huomioon taloudellinen, sosiaalinen ja poliittinen ulottuvuus. Lisäksi tulisi tarkastella kaikkien näiden tekijöiden vaikutusta toisiinsa. Laine kohdistaa tarkastelunsa ennen muuta kirkon ja uskonnollisen yhteisön toimintaan, sillä näiden vaikutus lukutaidon varhaisvuosisatoina oli olennainen.

Laine tekee toisenkin olennaisen rajauksen. Hän tarkastelee lukutaitoa sosiaalisena ja yhteiskunnallisena ilmiönä, ei vain yksilön kykynä lukea. Tähän viittaa alaotsikon sana "lukukulttuuri". Lukutaitoa määrittävät ja ohjailevat poliittiset ja 
yhteiskunnalliset voimat. Se syntyy kommunikatiivisessa kehässä, jonka luovat kirjat, niiden kirjoittajat, julkaisijat ja jakelijat sekä lukemisen paikat. Lukutaidon tavoitteet puolestaan määrittyvät aikakauden poliittisten tai uskonnollisten virtausten mukaisesti.

Teosen alkuosan pohdinta lukutaidosta ja sen monipuolisuudesta sekä termien lukutaito ja literacy eroista on valaisevaa. Luku- ja kirjoitustaidon yhteys on nykyisin itsestään selvää, mutta aluksi suomalaisten lukutaito kulki vuosikymmenten ajan erillään kirjoitustaidosta. Monin paikoin Laineen tarkastelu on täysin linjassa esimerkiksi nykyisten opetussuunnitelmien kanssa, ja se taustoittaa hyvin monilukutaidon kontekstuaalista ja sosiaalista käsittelyä.

Kirjan pääjuoni ja siten myös luvut etenevät kronologisesti vuosisata kerrallaan, vaikka luvuilla on omat temaattiset painotuksensa. Johdantoa seuraavista käsittelyluvuista ensimmäinen esittelee 1600lukua, jolloin lukutaito-opetus liittyi kansanopetukseen ja toiminnan ohjaajina olivat piispat lukkarinkouluineen. Lukutaitoa opetettiin nimenomaan aikuisille. Enää ei riittänyt ulkoluku ja Raamatun opetusten toistaminen muistinvaraisesti; oli opittava lukemaan sisältä ja osoittamaan, että on myös ymmärtänyt lukemansa.

Luku 3 esittelee monipuolisesti lukemisen tapoja ja apuneuvoja. Tärkeä oli siirtymä ääneen lukemisesta hiljaiseen lukemiseen. Myös tekstin muoto ja typografia tulevat käsitellyiksi. Vaikka lukutaito alkoi vakiintua, se liittyi yhä tiiviisti uskontoon. Tämä yhteys jatkuu 180o-luvulle saakka.

1700-luvulla Suomeen tuli pietistinen herätysliike. Sen perusoppeihin kuului kristityn henkilökohtainen harras uskonelämä. Tämä vahvisti tarvetta lukea Raamattua, ja erilaiset pietistiset suuntaukset julkaisivat omia raamatunlukuoppaitaan. Kristityn velvollisuus oli perehtyä Raamattuun, lukea sitä sekä itsekseen että perhekunnalle ääneen. Herätysliikkeiden oppaat ja niiden avulla tehtävät uskonopin tulkinnat eivät olleet aina kirkolle mieleen. Rahvaan lukutaidosta ja lukemisen tavoista tulikin kilpakenttä, jossa kirkko ja sen herätysliikkeet kilpailivat oikeasta lukutavasta. Laine kuvaa kirkkohistorialliseen tutkimukseen kuuluvalla yksityiskohtaisuudella erilaisia pietismin suuntauksia ja niiden käsityksiä uskonelämästä ja lukutaidosta. Sille, joka tarttuu Laineen teokseen ymmärtääkseen, miten yhteiskunnat ovat rakentuneet lukutaidon ympärille, nämä pietistit ja herrnhutilaiset tuntuvat työläiltä sivupoluilta. Kirjan pääjuoni kulkee kuitenkin kirkkaana: ulkoluvusta kohti itsenäistä ja modernia lukemista.

160o-luvun lopulta alkaen lukemista ryhdyttiin opettamaan aikuisten sijaan lapsille. 1700-luvulla Suomessakin alettiin julkaista lapsille sopivaa oppimateriaalia. Alkuun aapiset sisälsivät katekismuksen niin kuin aikuisille tarkoitetut aineistotkin, mutta lasten kirjat painettiin isommilla kirjaimilla ja tekstiin lisättiin tavuviivat. Kuvitukseksi ilmestyi aapiskukko, samaan tapaan kuin ruotsalaisiin ja latinankielisiin aapisiin jo 1600-luvulla. Olisi hienoa, jos Laine olisi kertonut kirjassaan, miksi juuri aapiskukko - onhan kukko ollut aapisten ja koulukuvastojen vakioeläin yli 200 vuotta.

Kun lapset ja aikuiset olivat saaneet oppinsa, kääntyi huomio nuoriin. Ehtoolliselle pääsy oli jo katolisena aikana edellyttänyt kristinopin tuntemusta. 1700luvulle tultaessa piispat alkoivat etsiä keinoja syventää ehtoollisen ymmärtämistä. Syntyi rippikoulu, nuorten lukuopetus ja luetun ymmärtämisen kontrollointi.

Lasten ja nuorten opetuksesta ja heille suunnatuista opetusmateriaaleista alkoi siirtymä kohti modernia lukutaitoa. Lapsille suunnatut materiaalit - esimerkiksi kysymysten ja vastausten muotoon rakennetut kasteopetukset - olisivat pedagogisilta menetelmiltään kelvollisia tänäänkin.

Laine esittelee teoksessaan juuri uskonnollisen kirjallisuuden lukemista, mikä 
Suomen oloissa on luontevaa, olihan suurin osa kirjallisuudesta vielä 180o-luvun alkupuolelle asti uskonnollista. Keskeiset lukutaidon opettamisen välineet olivat Raamattu, katekismus ja näihin pohjautuvat aapiset. Vasta kansakouluasetuksen jälkeen 1860-luvulla lukutaidon opetus alkoi hyödyntää maallisia aineistoja.

Laine kuvaa lukutaidon yhteiskunnallisen merkityksen hyvin. Lukutaito johti itsenäistymiseen: lukutaitoinen ei ollut vain passiivinen vastaanottaja ja kirkon ja esivallan käskytettävä. Lukutaitoinen kansalainen pystyi ilmaisemaan oman kantansa ja hyödyntämään myös kirjoitustaitoaan. Tämän osoittamiseksi kirjan loppuluvussa esitellään rahvaan joukosta nousseita lukijoita, joista tuli arkkivirsien sepittäjiä ja naisasian edistäjiä.

Laineen kirja on tiivis ja yhtenäinen esitys suomalaisen lukukulttuurin kehityksestä. Teksti on miellyttävää lukea. Sananvalinnat ovat täsmällisiä ja huolellisesti mietittyjä. Teksti etenee luvuittain ja lukujen sisällä päämäärätietoisesti. Runsaiden lähdeviittausten avulla saa tuntuman kirjahistorian tutkimusperinteeseen ja löytää hyödyllistä lisäluettavaa. Lähdeviitteet on esitetty alaviitteinä, jolloin lukija voi halutessaan myös ohittaa ne. Viitetekniikka on kuitenkin mielestäni hieman ongelmallinen. Viitteet ovat monin paikoin kappaleen lopussa, ja yhteen viitteeseen on koottu kaikki kappaleessa hyödynnetyt lähteet. Tämä vaikeuttaa olennaisten lähdeteosten tunnistamista.
Laine kuvaa lukutaidon itsenäistävää ja täysivaltaistavaa voimaa: lukutaitoisen ei tarvitse tyytyä kirjojen sisältöihin sellaisenaan. 1700-luvulla kirjan omistaja saattoi kommentoida kirjaa kirjoittamalla jälkipolvia varten arvion kanteen. Nykyaikana tuon kannanoton voisi kirjoittaa sosiaaliseen mediaan omaan kirjablogiin. Muutenkin kirjaa lukiessa syntyy tuon tuosta analogioita tähän päivään. Lukutaito oli ja on edelleen yhteisön väline, olipa kyse työstä, koulutuksesta tai kansalaisen elämänhallinnasta. Luku- ja kirjoitustaidon avulla kansalainen saa äänensä kuuluviin ja voi vaikuttaa niin omaan kuin ympäristönsä elämään. Lukutaidottomuus oli jo 170o-luvulla sosiaalisesti hävettävää. Samanlaista keskustelua käydään nykyään, kun kaikkien lukutaito ei peruskoulun päätyttyä anna välineitä opintoihin tai työpaikan hankkimiseen. Nyt lukutaidottomuutta ei nähdä niinkään häpeällisenä vaan yhteiskunnasta syrjäyttävänä.

Laineen yleisesitys kirjan ja lukemisen sosiaalihistoriasta sopii hyvin omaan aikaamme - olemmehan jälleen lukutaitokeskustelujen ytimessä, kun Pisa-tuloksia ja peruskoululaisten heikentynyttä lukutaitoa tarkastellaan. Lukutaidon pitkä perspektiivi auttaa kysymään, millä lukutaitoa perustellaan ja millaisena yksilön ja yhteisön rooli lukukulttuurissa nähdään.

PIRJo HiIdENMAa etunimi.sukunimi@helsinki.fi

Kirjoittaja on tietokirjallisuuden professori Helsingin yliopistossa. 